\title{
Research into Reform of the Piano Teaching under the Educational Background of Cultural Diversity
}

\author{
Sha Su \\ Department of Music, Hankou University, Wuhan 430212, China \\ 9543073@qq.com
}

Keywords: diverse cultural education background; piano teaching; cultural education

\begin{abstract}
Under the educational background of cultural diversity, it has been an imperative to reform the piano teaching style and teaching content so that the piano teaching can accommodate to era development requirements. This paper first expounds on the status of piano teaching against the backdrop of diverse cultural education, and then analyze problems existing in the current piano teaching. Following that, causes behind the problems are examined. Finally, combining relevant examples, strategies to reform the current piano teaching under the educational background of cultural diversity are put forward.
\end{abstract}

\section{Introduction}

The most striking characteristic of the diverse cultural background is cultural diversity. Because of emergence of cultural diversity, people's aesthetics and values have been changed, adding great variety to people's spiritual and cultural world[1]. Meanwhile, development of diverse cultures has exerted a significant impact on the traditional culture. In the field of teaching, it is necessary to reform the teaching styles and teaching content under the background of cultural diversity. With the advent of the new era, piano teaching has been endowed with new characteristics[2]. In order to accommodate to these new characteristics, specific strategies should be adopted to optimize piano teaching under the educational background of cultural diversity[3].

\section{Status of piano teaching under the diverse cultural background}

Under the diverse cultural education, the current piano teaching mainly has the following problems. (See Fig. 1)

Table 1. Analysis of problems with piano teaching under the educational background of cultural diversity

\begin{tabular}{cc}
\hline Problems & Causes \\
\hline Lack of the teaching faculty & $\begin{array}{c}\text { Lack of the number of cultural teachers } \\
\text { and a low professional title of cultural } \\
\text { teachers }\end{array}$ \\
Outdated teaching system & $\begin{array}{c}\text { Inheritance of the European piano } \\
\text { education model in the teaching system }\end{array}$ \\
Lack of cultural education & $\begin{array}{c}\text { Focus on piano playing skills and } \\
\text { ignorance of cultural education }\end{array}$ \\
\hline
\end{tabular}

As one observes in Table 1, lack of the teaching faculty is mainly caused by a relatively small number of teachers providing cultural education. Even if there are any, these teachers are low in their professional title. Among the piano teaching faculty in schools, there are many specialized piano 
teachers holding a high professional title. However, cultural teachers are not only smaller in number, but lower in their professional title. At school, cultural courses account for a smaller percentage. Students have no access to quality cultural education. The aging educational system is mainly caused by China's late start in the field of piano teaching. In terms of the teaching system, many schools are still following the European piano educational model. The teaching content obviously lacks diversity and is deviated from the current diversified cultural background. This will seriously restrict development of students' new thinking. School's ignorance of cultural teaching is mainly to blame for lack of cultural education [4].

\section{Measures to reform piano teaching under the educational background of cultural diversity}

\subsection{Strengthen the cultural teaching faculty}

The cultural teaching faculty in some schools is crying for strengthening. On the one hand, cultural teachers with a higher degree of professionalism should be introduced to ensure quality of cultural education at school. While recruiting cultural teachers, schools should pay special attention to assessment of their qualifications and credentials. On the other hand, after these cultural teachers are employed, their cultural qualities should be further reinforced. Training should be provided for these piano teachers to hone their cultural qualities. Take China's Inner Mongolia Normal University for example. The school attaches great importance to the teaching faculty providing cultural education for students majoring in Music. The proportion of cultural courses has been increased for students majoring in Piano at an attempt to effectively improve cultural accomplishments and upgrade the quality of cultural education. Under the educational background of cultural diversity, the teaching reform bears vital significance, and is referential to other schools in China.

\subsection{Enhance expansion of the piano teaching content}

Under the background of cultural diversity, the teaching content of piano should be expanded instead of being confined to the traditional European piano works. It is necessary to increase to the number of Asian piano works and Latin American piano works in classroom teaching to further broaden students' horizon. Diversification of artworks for teaching can effectively guide students and fully tap students' potential to stimulate students' innovational thinking. Additionally, famous piano works with Chinese characteristics can be introduced to not only lead students to study Chinese music, but also arouse students' patriotism. When teaching European piano works, teachers should not limit the teaching materials to the classic works. Instead, more pop elements should be included to increase depth and breadth of piano education. Besides, diversity of the teaching evaluation should be ensured. Strategies to maintain diversity of evaluation methods are shown in Table 2 below.

Table 2. Diverse evaluation strategies

\begin{tabular}{cc}
\hline $\begin{array}{c}\text { Diverse strategies for piano teaching } \\
\text { evaluation }\end{array}$ & Causes of implementation \\
\hline $\begin{array}{c}\text { Establishment of a diverse piano teaching } \\
\text { evaluation system }\end{array}$ & $\begin{array}{c}\text { Reasonability of the evaluation system } \\
\text { decides the scientific nature of the diverse } \\
\text { teaching content. }\end{array}$ \\
$\begin{array}{c}\text { Building of a piano teaching evaluation } \\
\text { team }\end{array}$ & $\begin{array}{c}\text { The evaluation team is the implementer } \\
\text { of evaluation system standards. } \\
\text { Implementation efficiency of the diverse } \\
\text { piano teaching evaluation system is decided } \\
\text { by evaluation skills. }\end{array}$ \\
\hline
\end{tabular}

As one observes in Table 2, schools should draw up a corresponding evaluation system oriented towards the teaching content, build a professional evaluation team, and propose relevant measures to 
improve shortcomings of the current piano teaching. All these measures adopted can ensure efficiency of the piano teaching content.

\subsection{Optimization of piano teaching styles}

Under the background of cultural diversity, the single piano teaching style cannot meet the diversified demands. This necessitates optimization of the piano teaching styles. The specific optimization strategies are shown in Table 3.

Table 3. Specific strategies for optimization of piano teaching styles

\begin{tabular}{cc}
\hline Optimization strategies & Specific measures \\
\hline Changes of the original teaching concepts & $\begin{array}{c}\text { Guarantee consistency between the } \\
\text { teaching concepts with the modernized } \\
\text { teaching concepts. }\end{array}$ \\
Changes of the original teaching styles & $\begin{array}{c}\text { Let perceptivity education dominate in } \\
\text { teaching activities. }\end{array}$ \\
\hline
\end{tabular}

According to Table 3, strategies to optimize piano teaching styles can be mainly divided into two aspects. First, the original teaching concepts should be changed. Under the educational background of cultural diversity, piano education should show more foresight. Not only should it realize the core of the current social and art development, but also it should accommodate to the future art taste and upgrade the piano teaching concepts to the globalization level. Second, the current teaching styles should be reformed. Schools should recruit piano teachers with advanced teaching concepts to promote transformation of teaching methods of the teaching faculty. Perceptivity education is an educational style which not only teaches students piano knowledge and skills, but also deepen students' understanding of the art of piano. By doing so, teachers can lead students to learn the social background of music and try to figure on the ideas of the composers.

Apart from strengthening of piano teaching, piano practice should also be enhanced. In recent years, teaching bases and students' performance bases have been built in Shandong, Heilongjiang, Hebei, Jiangxi, and Guizhou. This is of vital significance to development of piano talents. Hence, Chinese schools should actively build bases for students' practice, and expand the focus of art practice to Chinese's music culture and international exchange. For example, the China Conservatory of Music once organized piano teachers and students to hold a concert in Salzburg for music exchange.

\subsection{Increase of attention to cultural education}

In piano teaching, cultural education is important. Different forms, such as the art of painting, piano and literature, are interconnected. Schools should pay more attention to cultural education, and highlight its importance. Students should be encouraged to grasp more diverse cultural knowledge and develop a stronger perceptivity of culture. As their understanding of piano works deepens, their performance effects will be improved. Meanwhile, efforts should be made from different perspectives to improve students' art perceptivity so that students' piano performance skills can scale a new height. Additionally, employment concepts of students should be actively transformed. Learning piano is to improve one's aesthetic accomplishments rather than to find a high-income job.

\section{Conclusions}

To sum up, this paper examines major problems in piano teaching under the educational background of cultural diversity. Strategies, including enhancing the cultural teaching faculty, expanding the piano teaching content, optimizing the piano teaching style and increasing attention to cultural education, can further deepen reform of piano teaching. This is of vital significance to improvement of the piano teaching quality and development of piano talents. More importantly, the 
teaching model can be reformed to be in consistent with the development trend of the current era.

\section{References}

[1] Awramiuk A. Curriculum reform and the educational content in geography within polish cultural diversity[J]. Simiolus Netherlands Quarterly for the History of Art, 2011, 6(1):1-3.

[2] Lynch S. "Science for all” is not equal to “one size fits all”: Linguistic and cultural diversity and science education reform[J]. Journal of Research in Science Teaching, 2001, 38(5):622-627.

[3] Hilferty F. Teacher professionalism and cultural diversity: Skills, knowledge and values for a changing Australia[J]. Australian Educational Researcher, 2008, 35(3):53-70.

[4] Dawn Joseph, Jane Southcott. 'Opening the doors to multiculturalism': Australian pre-service music teacher education students' understandings of cultural diversity[J]. Music Education Research, 2009, 11(4):457-472. 